\title{
Interpretasi Struktur Geologi Di Laut Aru Selatan, Maluku Berdasarkan Data Seismik 2D Multi Channel
}

\author{
Arief Budiman Ustiawan ${ }^{1 *}$, Tumpal Bernhard Nainggolan ${ }^{2}$, Reddy Setyawan ${ }^{1}$ \\ ${ }^{1}$ Departemen Teknik Geologi, Universitas Diponegoro, Jl. Prof. Sudarto SH, Tembalang, Semarang \\ ${ }^{2}$ Pusat Penelitian dan Pengembangan Geologi Kelautan, J1. Dr. Djundjunan No. 236, Bandung
}

\begin{abstract}
Abstrak
Produksi minyak di Indonesia telah dimulai sejak tahun 1885 ketika sumur minyak pertama di Indonesia berhasil berproduksi pada Kabupaten Langkat, Sumatera Utara. Faktor pemulihan yang rendah mengakibatkan produksi minyak di Indonesia telah menurun karena kurangnya eksplorasi dan investasi pada sektor minyak bumi. Salah satu metode geofisika yang digunakan dalam eksplorasi hidrokarbon yang pada umumnya memiliki kedalaman yang dalam yaitu adalah metode seismik. Penelitian ini bertujuan untuk melakukan interpretasi geologi terhadap penampang seismik sehingga menampilkan gambaran bawah permukaan. Pusat Penelitian dan Pengembangan Geologi Kelautan (PPPGL) merupakan unit penelitian dan pengembangan dibawah Kementerian Energi dan Sumber Daya Mineral yang melakukan tahapan pengambilan data seismik refleksi terutama di daerah laut. Tulisan ini menggunakan data seismik refeksi pada Line-14, Laut Aru Selatan, Maluku. Data metode seismik multi channel sebanyak 1 lintasan tersebut kemudian diproses menggunakan perangkat lunak pengolahan data seismik. Proses interpretasi menggunakan perangkat lunak interpretasi geologi dengan melakukan picking horizon dari batas formasi dan struktur geologi. Berdasarkan tahapan interpretasi, tatanan stratigrafi daerah penelitian memiliki kesebandingan atas Formasi Kemum, Formasi Kais, Formasi Klasafet, dan Formasi Klasaman bagian bawah. Berdasarkan interpretasi struktur geologi didapatkan kumpulan sesar normal yang dapat diindikasikan sebagai migration pathway dari hidrokarbon.
\end{abstract}

Kata kunci: seismik refleksi, tatanan stratigrafi, struktur geologi, Laut Aru Selatan

\begin{abstract}
Oil production in Indonesia has started since 1885 when the first oil wells in Indonesia succeeded in producing in Langkat, North Sumatra. Low recovery factors have resulted in oil production in Indonesia decreased since 1995 due to lack of exploration and investment in the petroleum sector. One of the geophysical methods used in hydrocarbon exploration which generally has deep depths is seismic method. This study aims to interpret the geology of the seismic cross section so that it displays a subsurface image. Marine Geological Institute (MGI) is a research and development unit under the Ministry of Energy and Mineral Resources that carries out the stages of seismic reflection data aquisition, especially in the sea area. This study uses seismic data Line-14 on South Aru Sea, Maluku. The multi channel seismic method data is then processed using seismic data processing software. The process of interpretation uses geological interpretation software by picking horizon from formation boundaries and geological structures. Based on the stages of the interpretation of the stratigraphic order the study area is composed of the Kemum Formation, Kais Formation, Klasafet Formation, and the lower Klasaman Formation. Based on the interpretation of the geological structure, a collection of normal faults can be indicated as a migration pathway of hydrocarbons.
\end{abstract}

Keywords: seismic reflection, stratigraphic order, geological structure, South Aru Sea

\section{PENDAHULUAN}

Produksi minyak di Indonesia telah dimulai sejak tahun 1885 ketika sumur minyak pertama di Indonesia berhasil berproduksi pada Kabupaten Langkat, Sumatera Utara (Bartlett,
1986). Saat ini, beberapa lapangan minyak di Indonesia masuk ke dalam kategori lapangan tua. Faktor pemulihan yang rendah mengakibatkan produksi minyak di Indonesia telah menurun karena kurangnya eksplorasi dan

*) Korespondensi : arief@student.undip.ac.id 
investasi pada sektor minyak bumi. Target-target produksi minyak yang telah ditetapkan oleh pemerintah pada setiap awal tahun selalu gagal dicapai karena kebanyakan produksi minyak di Indonesia berasal dari ladang-ladang minyak yang sudah termasuk ke dalam kategori lapangan tua.

Pelaksanakan tahapan eksplorasi minyak dan gas bumi diawali dengan interpretasi kondisi geologi bawah permukaan untuk penentuan lokasi prospek hidrokarbon. Gambaran bawah permukaan dapat ditunjukkan dengan pendekatan metode-metode geofisika. Salah satu metode geofisika yang digunakan dalam eksplorasi hidrokarbon yang pada umumnya memiliki kedalaman yang dalam yaitu adalah metode seismik. Metode seismik merupakan sebuah metode dalam geofisika eksplorasi yang memiliki prinsip kerja merekam getaran menggunakan penerima atau receiver, getaran tersebut merupakan hasil refleksi atau refraksi gelombang yang berasal dari sumber getaran (source) oleh lapisan batuan di bawah permukaan.

Pusat Penelitian dan Pengembangan Geologi Kelautan (PPPGL) merupakan instansi di bawah Kementerian Energi dan Sumber Daya Mineral yang melakukan tahapan pengambilan data seismik terutama di daerah laut. Tahapan yang dilakukan oleh Pusat Penelitian dan Pengembangan Geologi Kelautan meliputi tahapan akuisisi, pemrosesan, hingga tahap interpretasi. Dalam tahapan akusisi hingga pemrosesan pada umumnya dilakukan oleh ahli geofisika sedangkan pada tahapan interpretasi dilakukan oleh ahli geologi. Pada tulisan ini dijabarkan mengenai tahapan pengolahan data hingga interpretasi dalam metode seismik di laut.

Data yang digunakan pada karya tulis ini terdiri atas satu lintasan dari data yang diakusisi oleh Pusat Penelitian dan Pengembangan Geologi Kelautan (PPPGL) di Perairan Aru Selatan yaitu Line-14 (Gambar 1). Karya tulis ini bertujuan untuk melakukan interpretasi geologi terhadap penampang seismik tersebut. Interpretasi penampang seismik bertujuan untuk menampilkan gambaran informasi geologi dari hasil pengolahan data seismik dengan dukungan atribut-atribut seismik (Roden, 2016). Dengan mengetahui gambaran informasi geologi berupa struktur geologi maupun stratigrafi maka dapat diketahui indikasi awal keterdapatan hidrokarbon di Perairan Aru Selatan.

\section{Seismik Multi Channel}

Metode seismik refleksi adalah metode seismik yang memanfaatkan gelombang pantul dari hasil injeksi sumber gelombang yang umumnya berupa ledakan menggunakan dinamit sebagai sumber (source) pada bidang reflektor (batas pelapisan batuan) (Permana dan Triyoso, 2015). Metode seismik refleksi merupakan metode yang paling tepat dalam survei eksporasi

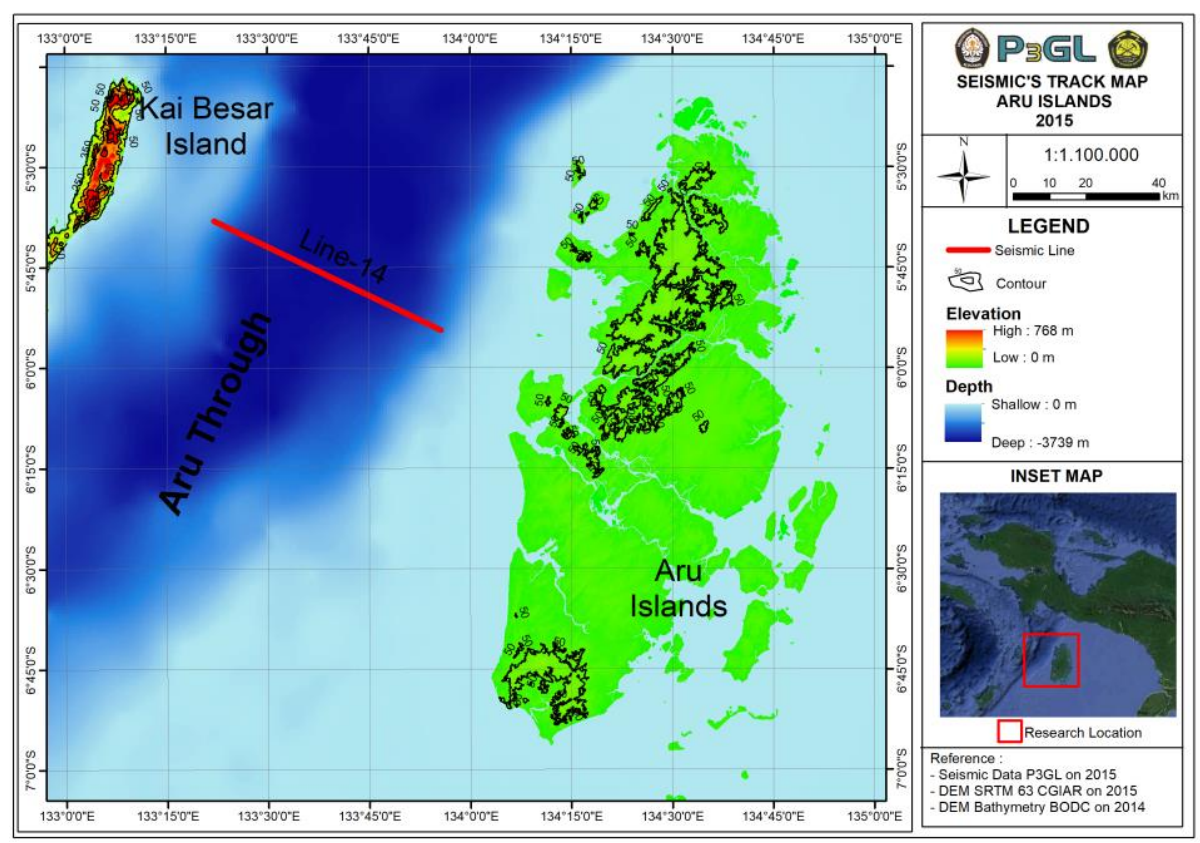

Gambar 1. Daerah Penelitian Perairan Aru Selatan 
hidrokarbon atau minyak bumi. Keuntungan metode seismik refleksi adalah dapat mendeteksi variasi baik lateral maupun kedalaman dalam parameter fisis yaitu kecepatan gelombang seismik dan dapat menginterpretasikan kenampakan struktur di bawah permukaan bumi serta membatasi kenampakan stratigrafi dan beberapa kenampakan pengendapan.

Seismik metode multi channel yaitu sistem perekaman data lapangan terdiri dari satu sumber seismik dan banyak penerima, gelombang-gelombang seismik refleksi tiba ke permukaan hampir bersamaan sehingga hasil yang didapatkan lebih jelas dibandingkan metode single channel. Pada metode multi channel ini karena terdiri dari banyak penerima maka akan menghasilkan demutiple atau perulangan lapisan yang dapat menggangu interpretasi sehingga harus dihilangkan (Ikeda dan Tsuji, 2016).

\section{Geologi Regional}

Pada daerah penelitian memiliki tatanan stratigrafi yang memiliki basement berupa batuan pre-tersier yaitu Formasi Kemum memiliki batuan dijumpai berumur Paleozoikum
Akhir, Mezosoikum, dan Kenozoikum yang menindih secara tidak selaras dan menyudut terhadap blok basement pada Cekungan Wokam, Maluku. Formasi Kemum yang memiliki litologi batusabak, filit greywacke, dan kuarsit berumur Silur hingga Devon (Gumilar, 2017).

Formasi Fumai terdiri dari batupasir, batulempung, batugamping dan dolomite yang diendapkan dalam lingkungan pengendapan yang berbeda-beda, tidak selaras menumpang di atas batuan metamorf Formasi Kemum (Charlton dkk., 1990).

Formasi Sirga diendapkan secara tidak selaras di atas batugamping Formasi Fumai, tetapi ke arah daerah tinggian Formasi Sirga membaji di atas batuan dasar. Formasi Sirga yang ditemukan di kampung Sirga terdiri dari batupasir kuarsa, batupasir konglomeratan dengan sisipan batulempung abu-abu dan batubara, batupasir abu- abu yang mengandung lapisan-lapisan tipis konsentrat fosil-fosil sisa tanaman. Formasi Kais bagian bawah yang berumur Miosen Awal terdiri dari batugamping paparan dan batugamping terumbu yang disebut sebagai horizon intra-Kais dan hanya berkembang di daerah Sub-Cekungan Matoa

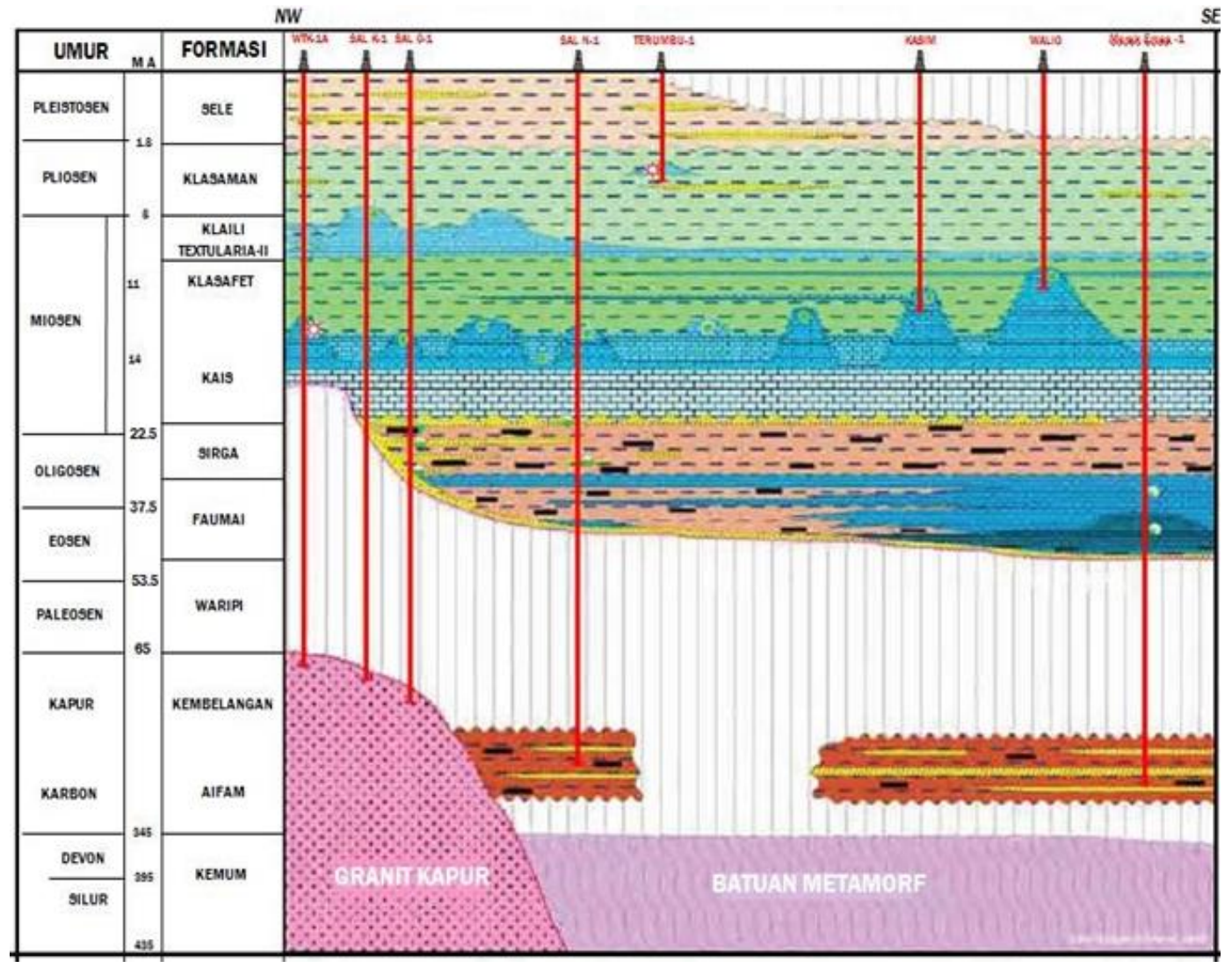

Gambar 2. Stratigrafi Regional Daerah Penelitian (Pireno, 2005) 
di bagian utara Cekungan Salawati (Granath dkk., 2010). Batuan-batuan karbonat ini diendapkan di daerah paparan laut dangkal yang luas. Pada daerah yang mempunyai energi gelombang yang lebih besar batugampingnya tumbuh sebagai batugamping terumbu dan pada daerah yang mempunyai energi rendah berkembang sebagai batugamping paparan dan batulempung gampingan.

Formasi Klasafet terdiri dari batulempung dengan sisipan-sisipan batugamping tipis yang diendapkan pada saat mulai terjadinya fase transgresi setelah pengendapan batugamping Formasi Kais dalam lingkungan pengendapan laut dangkal tertutup yang membaji di atas batugamping Kais di bagian utara dan selatan (Corrke dkk, 1997).

Bersamaan dengan mulai aktifnya sesar mendatar Sorong, Cekungan Salawati juga mengalami penurunan yang intensif selama kala Pliosen sehingga diendapkanlah Formasi Klasaman yang diendapkan secara selaras di atas Formasi Klasafet. Formasi Klasaman terdiri dari batulempung laut dalam yang bersisipan batupasir dan batugamping. Karena sangat intensifnya penurunan cekungan sehingga Formasi Klasaman mempunyai ketebalan yang sangat signifikan yaitu mencapai sekitar 7.0008.000 kaki (Gambar 2).

\section{METODOLOGI}

Data yang digunakan pada karya tulis ini terdiri atas satu lintasan dari data yang diakusisi oleh Pusat Penelitian dan Pengembangan Geologi Kelautan (PPPGL) di Laut Aru Selatan yaitu Line-14. Data seismik hasil akusisi pada Laut Aru Selatan ini memiliki format yaitu SEG-D. Pada proses akusisi data seismik ini menggunakan metode multi channel yaitu sistem perekaman data lapangan terdiri dari satu sumber seismik dan banyak penerima, gelombang-gelombang seismik refleksi tiba ke permukaan hampir bersamaan sehingga hasil yang didapatkan lebih jelas dibandingkan metode single channel.

\section{Pengolahan Data}

Pada pengolahan data dilakukan beberapa koreksi untuk menghasilkan penampang seismik yang baik. Salah satu koreksi yang dilakukan adalah migrasi. Migrasi berdasarkan tipenya dibagi menjadi migrasi sebelum stack (pre stack migration) dan migrasi sesudah stack (post stack migration) (Yilmaz, 1987). Penggambaran struktur penampang pre stack mampu menggambarkan struktur sesar dengan lebih baik dibandingkan post stack. Migrasi Tipe PSTM dilakukan dua kali dengan kecepatan RMS yang berbeda (Nainggolan dan Setiady, 2017). Kecepatan RMS awal diperoleh dengan mentransformasi langsung kecepatan stacking menjadi kecepatan RMS. Kecepatan stacking diperoleh dari picking kecepatan secara vertikal pada semblance yang memiliki energi maksimum ditandai warna merah. Dalam proses melakukan picking harus menunjukkan pola yang bernilai positif atau bergerak ke arah kanan.

\section{Analisis Data}

Pada tahapan analisis data seismik hasil pengolahan data dianalisis menggunakan perangkat lunak interpretasi geologi. Penggunaan perangkat lunak interpretasi geologi karena dapat membaca format BMP sehingga lebih mudah dalam proses interpretasi.

\section{HASIL}

Data seismik hasil akusisi pada Perairan Aru Selatan ini memiliki format yaitu SEG-D dengan panjang lintasan sepanjang $30,35 \mathrm{~km}$. Pada proses akusisi data seismik ini menggunakan metode multi channel yaitu sistem perekaman data lapangan terdiri dari satu sumber seismik dan banyak penerima, gelombang-gelombang seismik refleksi tiba ke permukaan hampir bersamaan sehingga hasil yang didapatkan lebih jelas dibandingkan metode single channel. Informasi yang terdapat pada proses informasi antara lain adalah jumlah tembakan yang dilakukan sebanyak 2.751 tembakan dengan receiver interval sebesar $12,5 \mathrm{~m}$, source station interval sebesar $25 \mathrm{~m}$, kedalaman sumber sedalam 6 meter, kedalaman streamer sedalam 7 $\mathrm{m}$, jarak antar CDP sebesar $6,25 \mathrm{~m}$, group interval $12,5 \mathrm{~m}$, near offset sebesar $150 \mathrm{~m}$, dan far offset sebesar 887,5 m (Gambar 3). 


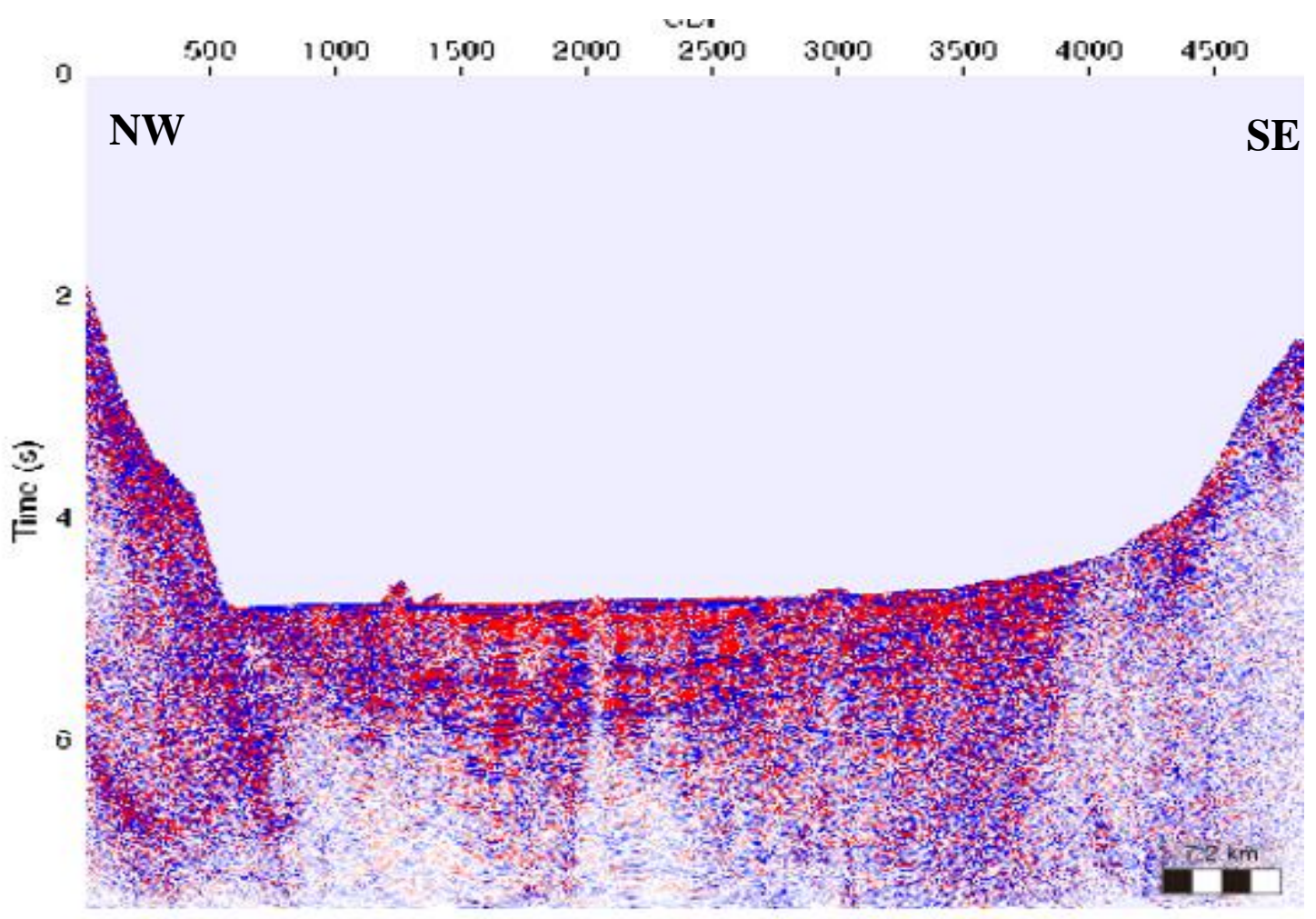

LIne-14 Pre-Stack TIme MIgration

Gambar 3. Tampilan Penampang Seismik Hasil Pengolahan

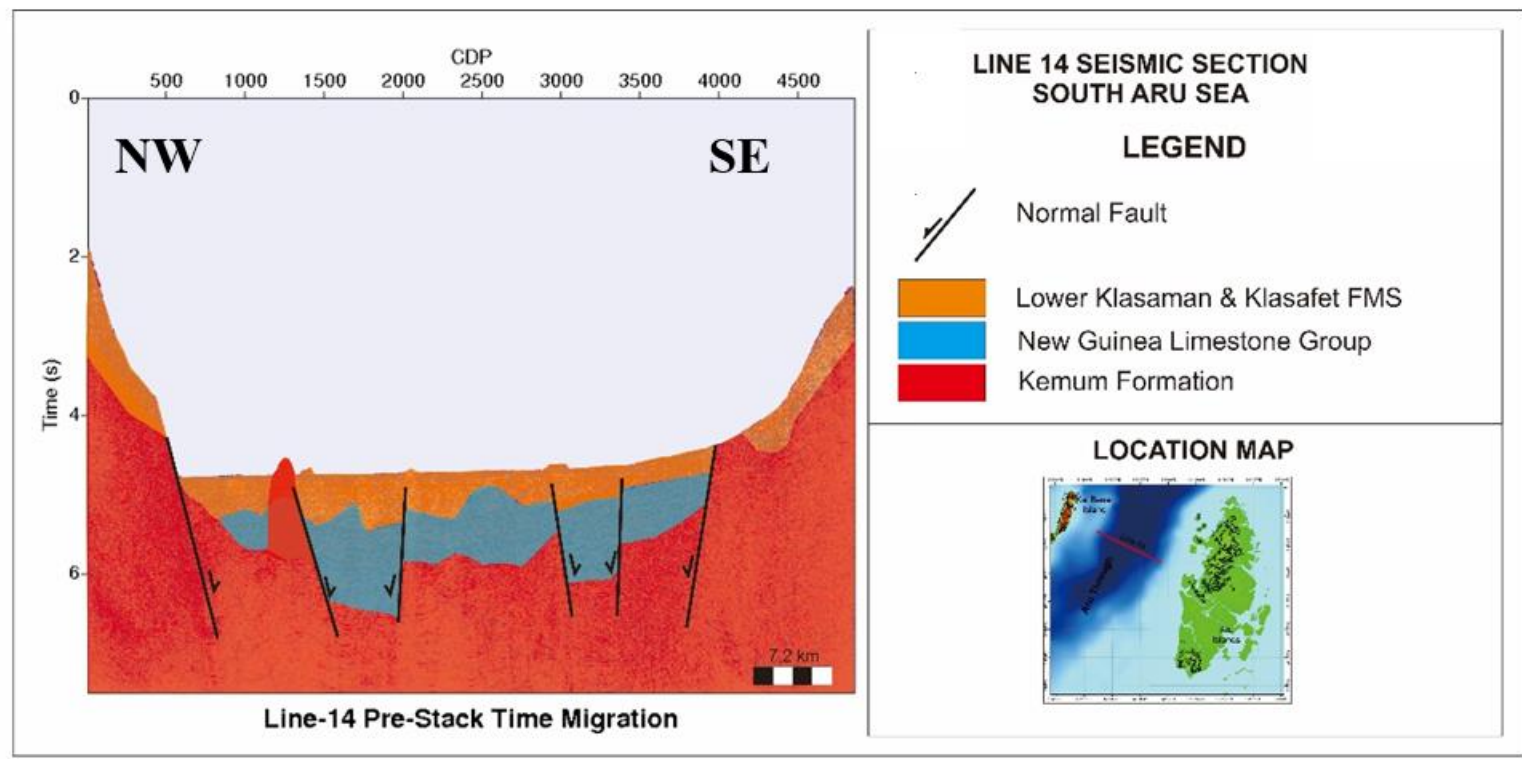

Gambar 4. Interpretasi Tatanan Stratigrafi dan Struktur Geologi Aru

\section{PEMBAHASAN}

Berdasarkan kenampakan reflektor seismik yang sama dengan penelitian yang dilakukan oleh Adhitama, dkk. (2017) pada bagian selatan Kepulauan Kai yang berada pada satu daerah dengan lokasi pengambilan data seismik yang digunakan pada karya tulis ini yaitu Perairan
Aru Selatan maka dapat dilakukan analisis mengenai tatanan stratigrafi daerah penelitian (Gambar 4).

Pada bagian paling bawah dari daerah penelitian yang ditunjukan dengan warna merah memiliki kenampakan reflektor seismik yang chaotic atau tidak beraturan yang merupakan 
kenampakan dari batuan beku atau metamorf. Berdasarkan studi literatur tersebut diinterpretasikan bahwa bagian ini sebanding dengan Formasi Kemum yang memiliki litologi batusabak, filit greywacke, dan kuarsit berumur Silur hingga Devon. Pada bagian kedua yang berada di atas bagian pertama yang ditunjukan dengan warna biru memiliki kenampakan reflektor yang sangat kuat serta terdapat bentukan mount yang menunjukan bahwa memiliki litologi berupa batugamping terutama batugamping terumbu. Berdasarkan studi literatur tersebut, diinterpretasikan bahwa bagian ini sebanding dengan grup New Guinea Limestone antara lain yaitu Formasi Fumai, Formasi Sirga, dan Formasi Kais.

Di antara ketiga formasi tersebut, yang memiliki litologi berupa batugamping terumbu adalah Formasi Kais yang terbentuk di paparan laut dangkal dengan energi gelombang yang rendah. Hal ini menunjukan adanya proses transgresi sehingga daerah penelitian menjadi daerah laut.

Bagian yang ketiga yang merupakan bagian paling muda pada daerah penelitian memiliki kenampakan reflektor pararel yang menunjukan bahwa memiliki litologi sedimen yang terendapkan pada energi rendah yaitu batulempung. Berdasarkan studi literatur tersebut diinterpretasikan bahwa bagian ini sebanding dengan Formasi Klasafet dan Formasi
Klasaman bagian bawah yang memiliki litologi batulempung. Keberadaan batulempung menandakan bahwa kala Miosen Tengah hingga Pliosen terjadi proses transgresi kembali yang sehingga daerah yang sebelumnya berada di laut dangkal berubah menjadi laut dalam.

\section{Struktur Geologi}

Berdasarkan interpretasi struktur geologi didapatkan kenampakan ketidakmenerusan bidang reflektor seismik yang membentuk sesar normal (normal fault). Pada daerah penelitian ini terdapat beberapa kumpulan sesar normal yang membentuk graben.

Sesar tersebut menurut Setyanta (2010) membentuk palung Aru oleh proses pemekaran yang terjadi sejak Jura hingga Kapur Awal sebelum mengalami daerah ini mengalami inversi tektonik menjadi kompresi. Sesar ini mengalami reaktivasi pada kala Pleistosen ketika berlangsung akibat keberadaan sesar mendatar sehingga pada Formasi Klasaman yang berumur Pliosen juga dapat ditemukan struktur sesar normal ini (Hall dkk, 2017). Pada daerah penelitian ini diindikasikan bahwa sesar ini sebagai migration pathway dari hidrokarbon karena di daerah sekitar sesar ini memiliki reflektor seismik yang chaotic atau tidak beraturan disebabkan gelombang tidak terhantarkan dengan baik (Gambar 5).

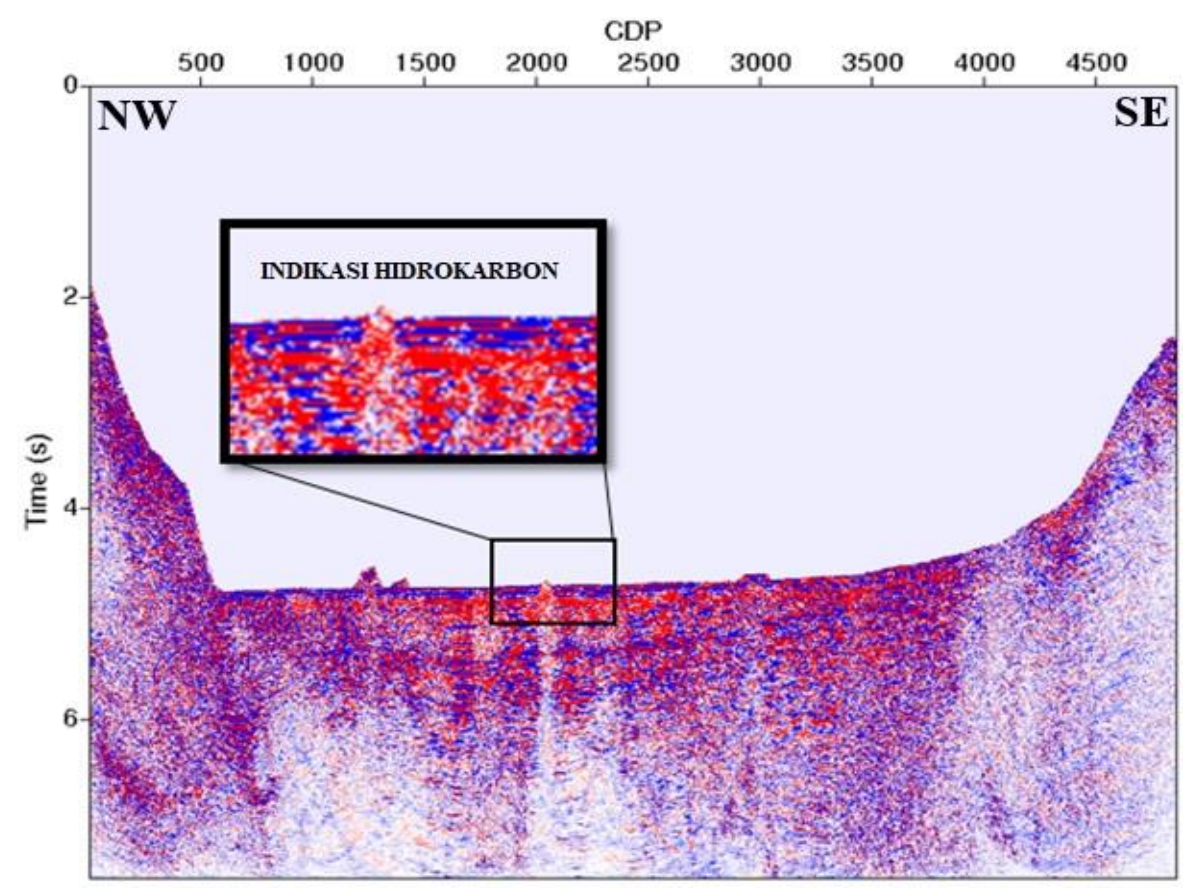

Gambar 5. Indikasi Awal Gas pada Line-14 Pre-stack Time Migration 


\section{KESIMPULAN}

Penggambaran struktur penampang pre stack time migration (PSTM) dari Line-14 mampu menggambarkan struktur sesar dengan baik sehingga interpretasi geologi dapat dilakukan lebih akurat. Berdasarkan kenampakan reflektor seismik tatanan stratigrafi daerah penelitian tersusun atas Formasi Kemum, Formasi Kais, Formasi Klasafet, dan Formasi Klasaman bagian bawah. Berdasarkan interpretasi struktur geologi, dapat diketahui kumpulan sesar normal yang mengindikasikan migration pathway dari hidrokarbon. Diperlukan analisis lebih lanjut seperti petrofisik untuk membuktikan kehadiran hidrokarbon pada daerah penelitian.

\section{UCAPAN TERIMA KASIH}

Penulis menyampaikan terima kasih kepada Pusat Penelitian dan Pengembangan Geologi Kelautan yang telah memberi izin pemakaian data serta supervisi dalam menyusun untuk penulisan artikel ini.

\section{DAFTAR PUSTAKA}

Adhitama, R., Hall, R., dan White, L.T. , 2017. Extension In The Kumawa Block, West Papua, Indonesia. Proceedings Indonesian Petroleum Association: Jakarta.

Bartlett, A.G., 1986. PERTAMINA: Perusahaan Minyak Nasional, terj. Mara Karma. Jakarta: Inti Idayu Press.

Charlton, T.R., Kaye, S.J., Samodra, H., dan Sardono. 1990. Geology of the Kai Islands: implications for the evolution of the Aru Trough and Weber Basin, Banda Arc, Indonesia. Marine and Petroleum Geology Journal. Vol 8: Texas.

Corrke, J.J., Villeneuve, M., dan Rehault, J.P., 1997. Stratigraphic succession of the Australian margin between Kai and Aru islands (Arafura Sea, eastern Indonesia) interpreted from Banda Sea II cruise dredge samples. Journal of Asian Earrh Science. Vol. 15. No. 4;5. h. 423-434 : Great Britain.

Granath, J.W., Christ, J.M., dan Emmet, P.A., 2010. Insights Into The Tectonics Of Eastern Indonesia From Arafuraspan, A Long-Offset Long-Record 2d Seismic Reflection Dataset. Proceedings Indonesian Petroleum Association: Jakarta.

Gumilar, I.S., 2017. Periode Deformasi Kenozoikum Kepulauan Aru, Cekungan
Wokam, Maluku. Jurnal Geologi dan Sumberdaya Mineral.

Hall, R., Patria, A., dan Adhitama, R., 2017. Seram, The Seram Trough, The Aru Trough, The Tanimbar Trough And The Weber Deep: A New Look At Major Structures In The Eastern Banda Arc. Proceedings Indonesian Petroleum Association: Jakarta.

Ikeda, T., dan Tsuji, T., 2016. Surface wave attenuation in the shallow subsurface from multichannel-multishot seismic data: a new approach for detecting fractures and lithological discontinuities. Journal The Earth, Planets and Space (EPS). Vol 68 : Jepang.

Nainggolan, T.B., dan Setiady, D., 2017. Practical Implementation of Multiple Attenuation Methods on 2D Deepwater Seismic Data: Seram Sea Case Study. Bulletin of the Marine Geology. Vol. 32, No. 1 : Bandung.

Pireno, G.E., 2005. Hydrocarbon potential of the West Salawati Block, West Papua, Prepared for Pearl Oil (Salawati) Ltd.

Permana, U. dan Triyoso, K.. 2015. Pengolahan Data Seismik Refleksi 2D Untuk Memetakan Struktur Bawah Permukaan Lapangan "X" Prabumulih, Sumatera Selatan. Alhazen Journal of Physics.

Roden, R., 2016. Seismic Interpretation in the Age of Big Data, Geophysical Insights. SEG International Exposition and 86th Annual Meeting, h. 4911-4915.

Setyanta, B,. 2010. Medan Gaya Berat dan Model Geodinamika di Sekitar Kepulauan Kai dan Kepulauan Aru, Maluku. Jurnal Sumber Daya Geologi. Vol 20. No.6, 2010 : Bandung.

Yilmaz, O., 1987. Seismic Data Processing. Society Exploration Geophysics. Tusla.1 
